\title{
"Normalizing" the Writing of Quebec History
}

\author{
Ronald Rudin, Making History in Twentieth-Century Quebec \\ (Toronto: University of Toronto Press 1997).
}

If there ever was a book clamouring to be written, it is Ronald Rudin's recent study of French-language historians of Quebec entitled Making History in Twentieth-Century Quebec. Since the appearance of Carl Berger's The Writing of Canadian History (1976), a seminal study of English-language Canadian historians, a glaring void persisted on the French-language side. True, this void was partially addressed by Serge Gagnon's two very short monographs, Quebec and Its Historians: 1840-1920 (1982) and Quebec and Its Historians: The Twentieth Century (1985). Unfortunately, neither study was very comprehensive nor very enlightening. Gagnon simply reaffirmed the revisionists' interpretation that all French-Canadian historians and their historiography remained distinctly "unprofessional" until the late 1940s. Also dealing with the topic were important historiographical essays by Fernand Ouellet, Pierre Savard, Denyse Baillargeon, Jean Blain, Fernand Harvey, J.-P. Coupal, Paul-André Linteau, Gérard Bouchard, and Andrée Lévesque, to name only a few. ${ }^{2}$

Nevertheless, only one of these authors, Fernand Ouellet, effectively contested the conventional wisdom about the origins and evolution of the discipline of history in French-speaking Quebec. This situation has not changed with the appearance of Jean Lamarre's recent monograph. Entitled Le devenir de la nation québécoise selon Maurice Séguin, Guy Frégault et Michel Brunet, 1944-69 (1993), Lamarre's focus, unfortunately, is almost exclusively on the Montreal School. Consequently, students of French-Canadian historiography continued to have difficulty, lacking an overarching, synoptic perspective. The dominance of the post-Montreal School revisionist historians had become so complete by the 1970 s that it was virtually impossible for students to conceive that there was any other way of perceiving either French Canada's past or the revisionists' interpretation of its historiography.

At the heart of the orthodox interpretation of Quebec history is the belief that professionalization of history only began with the arrival at the Universite de Montréal of three lay professors, namely Frégault, Brunet and Séguin in 1947. All the historians and their historical scholarship before their arrival on the scene were considered by the Montreal School, as well as its successor generation of revisionists, to be amateurish, clerical, elitist, with much of their work characterized as romanticized "great man" hagiography. The butt of most 
of their scathing critique, much of it indirect, was aimed at Canon Lionel Groulx who had been appointed to the first Chair of Canadian History at the Université de Montréal in 1915 where he remained attached until his death in 1967.

Even before the appearance of Making History in Twentieth-Century Quebec, Rudin's recent essays had sparked a long overdue debate about Québécois historiography. No doubt, his monograph will ensure that this controversial debate about the professionalization of history in Quebec, as well as about the nature and impact of the revisionist school's dominance, will become central to our understanding of Quebec's historiography. Paradoxically, taking his cue from the revisionists, Rudin turns their "modernization" thesis against them, proposing his very own "revisionist" thesis about the professionalization of history within Quebec's francophone community. Rudin's approach, on the surface, is very alluring but it has some of the same shortcomings which he attributes to the revisionists. For example, by analyzing Lionel Groulx exclusively as an historian rather than the enormously complex and multifaceted activist and historical actor that he really was, the novice reader will lack context for the full appreciation of Groulx as a professional historian. Readers and students would be well advised to consult the existing literature on Groulx. When read in conjunction with Rudin's assessment, Groulx becomes even more fascinating and complex.

Like Berger, Rudin believes there is a strong relationship between historical writing and the intellectual and socio-economic climate in which it was written. Unlike Berger, he does not believe that the practice of history in the twentieth century has seen any real marked progress towards that cherished but illusive goal of "objectivity." In short, he decries the celebratory tone of Berger's study, a tone which he argues is shared by the Québécois revisionist historians in their portrayal of their own work as well as that of the Montreal School vis-à-vis their predecessors.

Instead, Rudin has more affinity with the views of Peter Novick as expressed in his ground-breaking study, "That Noble Dream": The Objectivity Question and the American Historical Profession (1988). Indeed, rejecting the unabashed relativism of Hayden White and Dominick LaCapra, Rudin shares Novick's proposition that "historical objectivity was a form of 'salutary nonsense'; it was undefinable and unachievable but just the same it provided some direction for historians." (7) Thus Novick's qualified relativism helps Rudin set the stage for his revisionist account of the professionalization of history among the Québécois francophone élite. Paying close attention to what intellectual, social and cultural currents influenced them and how they perceived their own practice of history, Rudin demonstrates rather convincingly that most 
twentieth-century Quebec historians beginning with Groulx believed, "at least in a vague way, in the principle that historical conclusions were valid only if supported by documentary evidence." (8) In short, the modernization of the discipline of history parallelled that of many other sectors of the Quebec society - including all aspects of the economy.

By analyzing closely important developments in the practice of history in the early decades of this century, Rudin challenges the revisionists' claim that Canon Lionel Groulx was merely "an ideologue masquerading as an historian," (18) and that his peers, Thomas Chapais, Hector Garneau, and Gustave Lanctot contributed little to the advancement of the profession. Beginning with his 1906-1909 sojourn in western Europe, progressing rapidly after his 1915 appointment to the first Chair of Canadian History at l'Université de Montréal, and culminating in 1925 with the first Semaine d'histoire which he helped organize, Groulx developed into a mature, professional historian fully conversant with the new methodologies and approaches emerging within the discipline in both the Old and New Worlds.

One can see Groulx's evolution in his support for the more "scientific" approach to the past adopted by Hector Garneau in his revised and updated reissue of his grandfather's Histoire du Canada. Groulx also appreciated the work of Thomas Chapais and especially the more "scientific" approach of Gustave Lanctot despite the fact that he disagreed strongly with their political views. As was the case in English-speaking Canada, French-Canadian historians were sufficient in numbers by the mid-1920s to organize a moderately successful conference. While amateur and emerging professional historians intermingled, it was clear that a new dynamic had emerged. The professionals emphasized that they, unlike their amateur colleagues, understood that "history is both a science and an art. The historian must bring these qualities together to be worthy of the name." (45) Rather than merely describing, professional historians analyzed primary sources seeking the truth while realizing they could not be neutral. Pure positivists they certainly were not, but this was a far cry from being the amateurish "grande noirceur" historians as portrayed by the Montreal School and the revisionists.

In Rudin's view the emerging professionalization of history during the interwar years experienced a modest setback as the war came to an end. The setback came in the form of the 1944 eighth edition of Garneau's Histoire du Canada which was celebrated at the second Semaine d'histoire held the following year. The Histoire was completely shorn of its scholarly apparatus and its anticlericalism to make it more acceptable to the clergy and more accessible to students and the general public. The new edition reflected both the traditional 


\section{Left History 6.1}

nationalism and the clerical flavour of the Duplessis regime. Conference participants reflected the tension between amateur and professional, between the secular and the religious, and between the anti-nationalist and nationalist approaches to history. The amateur historians were pleased with the latest version of Garneau while anti-nationalist professional historians like Gustave Lanctot were furious. On the other hand, Groulx and his disciple, Guy Frégault, fully endorsed Garneau's combination of nationalism and scientific methodology and chastised Lanctot for ignoring Garneau's nationalism. In Rudin's estimation only modest progress had been achieved in the craft of history as the struggle for truth competed constantly with the historians' commitment to preaching the gospel of nationalism.

Chapters three and four deal with the rise and fall of the Montreal and Laval Schools in the 1950s and 1960s. The Montreal School blamed English Canada for the economic, cultural and political "backwardness" of Quebec's francophone nationality while the Laval School argued that French Canadians had no one to blame but themselves. The arrival of Groulx's three disciples, Frégault, Séguin, and Brunet coincided with the creation of the Department of History at l'Université de Montréal and the launching of the periodical Revue d'histoire de l'Amérique française in 1947. The professional training, the anticlericalism, the anti-traditional nationalism, and the statism of Groulx's disciples allowed them to lay claim to being the true founders of professional "scientific" history in Quebec. Rudin illustrates how they attempted discreetly to distance themselves from their clerical nationalist "amateur" mentor by proposing an iconoclastic reinterpretation of New France and the British Conquest of 1759-1763.

Rudin argues, convincingly, that their urban, middle-class, secular, statist, neo-nationalist history had much more in common with Groulx's approach than they, or their revisionist successors, either realized or were ever willing to acknowledge. Their self-proclaimed search for historical truth was subverted by their nationalist/secession agenda. Meanwhile, Groulx, who remained open to new ideas, continued to refine his "scientific" approach to French-Canada's increasingly complex past. This chapter constitutes the best analysis to date of the highly complex and often very bitter relationship between Groulx and his disciples, especially the irascible Brunet. Rudin reminds his readers that the scholarly production of Brunet and Séguin was, in many ways, inferior to that of Groulx. And yet, their neo-nationalist message was a very powerful catalyst for the coming Quiet Revolution of the 1960s with its regenerative impact on Québécois society and its institutions at all levels. Ironically, the Montreal School's secular nationalist moralizing accomplished what Groulx had failed to 
achieve with his clerical nationalist moralizing style of French-Canadian history.

Arguing that blinkered English-Canadian historians, such as Ramsay Cook and Michael Behiels, have been far too uncritical of the Laval School, Rudin attempts to demonstrate that the historical scholarship of Marcel Trudel, Jean Hamelin, Fernand Ouellet, and Claude Galarneau, while considerably better than that of the Montreal School, was badly marred at times by a pro-Canadian, pro-federalist political agenda. Often, the Laval school, especially Ouellet, merely paid lip service to their supposed single-minded search for historical truth. Rudin reminds readers that Laval's "French connection," especially with members of the Annales School was neither highly developed nor very sustained. Consequently, these contacts did not have the kind of impact on their historical approaches and research methods that revisionist historians like Lamarre claim. Laval historians took only what suited them and left the rest behind. In short, according to Rudin, conflicting ideologies continued to motivate all francophone historians and these ideologies distorted their scholarship in the same manner as they had in the time of Chapais and Groulx. Again, only marginal progress was achieved in the historiography.

Continuing in this vein, Rudin undertakes a highly critical analysis of the revisionist school which emerged in the early 1970s and retains, in his view, an unhealthy dominance over contemporary Québécois historiography. The revisionist school, a direct product of the Quiet Revolution of the 1950s and 1960s, is closely identified with the work of the urban historian, Paul-André Linteau, the political and constitutional historian, René Durocher, and the Marxist historian, Jean-Claude Robert. They made a conscious decision to deemphasize cultural, religious and linguistic cleavages and wrote a survey history of Quebec ${ }^{3}$ in which class cleavages were at the centre of their interpretation of the development of a pluralistic, urbanized and industrialized society within the territory of Quebec. They, and their colleagues, ${ }^{4}$ deliberately set out to demonstrate that Quebec's past, but especially that of its Francophone majority, was every bit as "normal" as that of every other society in North America.

By emphasizing economic and structural themes, the revisionists demonstrated to their satisfaction that Quebec and its majority Francophone community had never been economically, socially, culturally, politically, or institutionally backward in any way when compared with the neighbouring communities. In sum, despite the French language and culture and the omnipresence of the Catholic Church, there was very little that was truly distinctive about the Francophone community's response to Quebec's full integration into capitalist North America. Quebec simply comprised another 
region, albeit French-speaking, of the vast North American continent and its various communities responded normally and effectively to the deep socioeconomic and technological forces associated with capitalism which molded the continent's evolution and expansion. Indeed, Francophone Quebecers were no longer viewed merely as victims of capitalism but instead were portrayed as active agents in the process of its expansion throughout Quebec. The revisionists write a disemboweled and depersonalized history, the very antithesis of the "great man" approach adopted by Quebec historians from Garneau to Frégault via Groulx and Chapais. Just as important, it was not, according to Rudin, appreciably more "scientific" or "objective" than the history painted by any of their predecessors.

Rudin quite rightly identifies Louise Dechêne as the effective lynch-pin between the Montreal School and the revisionists. She is a New France specialist and practitioner of the Fernand Braudel, Pierre Goubert, and Emmanuel Le Roy Ladurie wing of the Annales School, which rejected the role of human agency and concentrated on long term economic and structural factors. Dechêne depicted the habitants and merchants of New France as rational, economic human beings "whose way of life reflected 'the normal pattern of European and colonial history'." (180) Her meticulously researched Habitants et marchands de Montréal au XVII siècle (1974) received lavish praise for its ostensible "value-free social scientist" methodology and for her rejection of the traditional discourse of difference. Yet, no reviewer realized that her work constituted an implicit political commentary and served as an important springboard for the revisionists who were determined to portray the francophone community of Quebec and their contemporary history as "normal" in every way.

Since there was such a neo-nationalist consensus of belief and approach, it was quite easy for Francophone historians of Quebec to agree upon a new homogeneous national history, one that was neither constrained nor encumbered by the need to incorporate religious, race, ethnic, and gender cleavages as fundamental socio-cultural determinants in the evolution of Quebec society. In Rudin's estimation, the capacity of the revisionist historians to respond to the "unique" problems of contemporary Quebec society is hampered very severely by this politically-driven "normalcy" approach to the past. From the outset, there was strong criticism of the revisionist school, most of it coming from Fernand Ouellet. Unfortunately, according to Rudin, "Ouellet's simplistic reduction of revisionists writing to a form of separatist propaganda provides a further example ... of the tendency he has shown throughout his career to take a good idea and push it to an illogical conclusion." (201) The legitimate elements of Ouellet's scathing critique were undermined by his refusal to accept some of the 
valid points of the revisionists, "such as the bad faith of the federal government or the general hostility of English-speakers." (202) Critics like Fernand Dumont, Louis Rousseau, and Serge Gagnon in his recent writings, propose that Francophone Quebecers return to their "golden age" in the past when they exuded a strong sense of community and "lived" a distinctive traditional sociocultural and religious identity.

In Rudin's judgment, their desire to return Quebecers to an historical "golden age" constitutes a dead end. He prefers the questioning of revisionists, like Gérard Bouchard, who are now wondering whether or not the "normalcy" model of Quebec's past had run out of steam and, like the Quiet Revolution, had outlived its usefulness. Using a comparative approach, Bouchard is interested in exploring what made Quebecers' response to industrial capitalism and urbanization different from that of Americans given the domination of a single religion. Along with Yvan Lamonde, Bouchard is exploring the concept of "Américanicite" in search of new answers to the orthodox question of Francophone Quebec's distinct and unique historical experience. ${ }^{5}$ Advocating a post-modern paradigm, a new generation of historians, Jocelyn Letourneau, Jean-Marie Fecteau and Gilles Breton, ${ }^{6}$ argue that coming to terms with the irrational, the spiritual, and the existential dimensions of human experience is crucial if historians are to provide a comprehensive explanation of all aspects and dimensions of Quebec's complex past. Rudin rightly points out that this neorevisionist school is a direct product of the growing disenchantment vis-à-vis the social and institutional reforms ushered in by the Not-so-Quiet Revolution of the 1960s and 1970s, reforms that did not produce the expected utopia but instead a generation of disoriented, disillusioned, and downright angry Francophone Quebecers facing the social disintegration of their society.

Other neo-revisionists, namely Robert Comeau and Michel Sarra-Bournet, take a more political tack. They have called for a reaffirmation of "the individual, his institutions and his ideas" and founded in 1992 the Bulletin d'histoire politique to reassert politics and political questions back into the agenda of historians. Meanwhile, others much further to the right, namely Stéphane Stapinsky, Benoît Lacroix, and Pierre Trépanier, have founded the Cahiers d'histoire du Québec au XXe siècle to critique the Montreal School and the revisionists for their excessively "scientific" approach to the past. They also want to defend their hero Lionel Groulx against charges of unprofessionalism by the revisionists and charges of racism and anti-semitism by writers like Esther Delisle. $^{7}$

Despite the emergence of neo-revisionist critics, the "revisionist interpretation remains the dominant perspective on Quebec's past - a situation 
that makes Quebec rather distinct." (216) This is all rather ironic considering that the revisionists set out to illustrate that Quebec was not distinct. In Englishspeaking Canada and other western countries, the new social history approaches, serving particularistic communities, dramatically undermined the very concept and the prospect of a homogeneous national history. On the other hand, in Quebec the new "scientific," value-free, social historians, who adopted uncritically the revisionist approach to the past, set the stage for the creation of a new national history, one charting uninterrupted march of the Québécois people towards modernity. Most assuredly, this is a whig history if there ever was one.

Rudin does not go on, as he did in an article for the Canadian Historical Review, to call for a meeting of minds between the revisionist and the antinationalist schools of historiography. $\mathrm{He}$ is quite satisfied that the emerging generation of neo-revisionist historians, like those of the past, will come to reflect, sooner or later, the increasing complexity of approaches within the historical profession as well as incorporating the new questions and problems created by the ongoing socio-economic and political changes taking place within Quebec society. This conclusion, I believe, is rather naïve considering that Rudin's overall analysis of Québécois historians and their scholarship demonstrates the overarching role played by all forms of nationalism in setting parameters for all professional historians regardless of their time or place. And yet, perhaps this is the only conclusion that Rudin could write. Because, for Rudin, historical objectivity remains a form of "salutary nonsense," which, like perfection, is for fools and angels but still must be set as the ultimate goal if even modest progress is to be achieved now and again. It is a bleak but, perhaps, realistic view of the discipline of Clio.

Michael D. Behiels

University of Ottawa

1 See Rudin's excellent bibliography for references to all these articles.

2 Paul-André Linteau, René Durocher, Jean-Claude Robert, Histoire du Québec contemporain. De la Confédération à la crise (Montréal 1979); Linteau, Durocher, Robert, et François Ricard, Histoire du Québec contemporain: Le Québec depuis 1930 (Montréal 1986).

${ }^{3}$ They include Serge Courville, Normand Séguin, Jacques Rouillard, Jean-Paul Bernard, Gérard Bouchard, René Hardy, Marie Lavigne, Yolande Pinard, Andrée Levesque, Fernande Roy, and Marta Danylewycz.

4 Gérard Bouchard et Yvan Lamonde, dirs. Québécois et Américains: La culture 
québécoise aux XIXe et XXe siècles (Montréal 1995).

5 Jean-Marie Fecteau, et als. La condition québécoise: enjeux et horizons d'une société en devenir (Montréal 1994).

${ }^{6}$ Esther Delisle, The Traitor and the Jew: Anti-Semitism and the delirium of extremist right-wing nationalism in French Canada from 1929-1939 (Montreal 1993). 